\title{
NEONATAL ASPHYXIA- DAMAGE TO NERVOUS SYSTEM- A STUDY OF 100 CASES
}

\author{
Shyamali Datta ${ }^{1}$
}

${ }_{1}^{1}$ Associate Professor, Department of Paediatrics, MGM Medical College/ Kishanganj Medical College, Bihar, India.

\begin{tabular}{l}
\hline BBSTRACT \\
As many outborn babies (mostly of unbooked mothers) are admitted in our Medical College NICU, perinatal asphyxia seems to be a \\
major factor leading to neonatal mortality and morbidity. Other than causing damage to different systems of body e.g. \\
cardiovascular and respiratory, damage to nervous system seems to be a significant percentage in our study.
\end{tabular}

\section{MATERIALS AND METHODS}

100 newborn babies were included in our study of varying birth weight, gestational age etc., but all were with history of neglected antenatal care, unattended delivery (mostly home). They presented with different features of e.g. seizures, coma, paresis, brisk jerks etc. Cranial ultrasonography was done in very critical cases. Neonatal sepsis was ruled out by 'Sepsis Screen.'

\section{RESULTS}

In a significant percentage of newborn babies with birth asphyxia (not crying after birth), blinking of eyes, apnoeic episodes, all manifestations of seizures, depressed alertness, diminished sucking and other reflexes were found. In cranial ultrasonography, a significant number of cases of periventricular vasodilatation was detected, especially in infants of early gestational age.

\section{CONCLUSION}

Elimination of different risk factors was identified in expectant mothers by proper antenatal care and monitoring, timely referral to higher centre, proper intervention will go a long way in preventing nervous system injury in newborn infants.

\section{KEY WORDS}

Perinatal Asphyxia; Damage to Nervous System.

HOW TO CITE THIS ARTICLE: Datta S. Neonatal asphyxia- damage to nervous system- a study of 100 cases. J. Evolution Med. Dent. Sci. 2018;7(36):4051-4055, DOI: 10.14260/jemds/2018/904

\section{BACKGROUND}

Perinatal asphyxia is the state of decreased oxygen delivery to the foetus or neonate resulting in inadequate tissue perfusion. It is the second most common cause of neonatal death after infection. Approximately, 23\% of the four million global deaths are attributable to asphyxia. ${ }^{1}$ Postasphyxial HIE occurs in about 1 to 2 per 1000 live births. ${ }^{2}$ Significant proportion of these infants die or survive with severe longterm morbidity. In India around 250,000 to 300,000 neonates die each year due to asphyxia, mostly in the first 3 days of life. WHO defined birth asphyxia as "failure to initiate and sustain breathing at birth." And with an Apgar score of $<7$ at one minute of life, resulting in impending or actual cessation of apparent life. $90 \%$ of asphyxia events occur in the antepartum or postpartum periods as a result of placental insufficiency. ${ }^{3}$

After an episode of asphyxia and ischaemia, anaerobic metabolism causes an increased amounts of lactate, inorganic phosphates, glutamate as well as free radicals. They are toxic and lead to damage of multiple organs of body like-

'Financial or Other Competing Interest': None.

Submission 09-05-2018, Peer Review 18-08-2018,

Acceptance 25-08-2018, Published 03-09-2018.

Corresponding Author:

Dr. Shyamali Datta,

60/129,

Golf Gardens $B$,

Kolkata-700033,

West Bengal, India.

E-mail: data.shyamali@gmail.com

DOI: $10.14260 /$ jemds $/ 2018 / 904$

\section{(c) $(7)$}

- CNS- Hypoxic Ischaemic Encephalopathy (HIE), infarction, intracranial haemorrhage, seizures, cortical atrophy.

- CVS- Myocardial ischaemia, poor contractility, hypotension.

- Pulmonary- Pulmonary hypertension, pulmonary haemorrhage, respiratory distress syndrome.

- Renal- Acute tubular or cortical necrosis.

- Adrenal- Haemorrhage.

- Gastrointestinal- Perforation, ulceration, necrosis.

- Metabolic- SIADH, hypocalcaemia, hyponatraemia, hypoglycaemia, myoglobinuria.

- Integument- Subcutaneous fat necrosis

- Haematology- DIC.

This multiple organ dysfunction is the reason for such mortality and morbidity associated with birth asphyxia. ${ }^{3}$ Death may occur in neonatal period itself or there may be lifelong handicaps in the form of mental retardation, cerebral palsy, seizure disorder etc. Risk of cerebral palsy is about 5 to $10 \%$ compared to $0.2 \%$ in general population. Most cerebral palsy is not related to perinatal asphyxia. ${ }^{4}$ Newer modalities of treatment are being developed to minimize the morbidity and mortality. The most promising among them is therapeutic hypothermia. It has been established that both head and body cooling are safe, effective and decrease the risk of brain injury in infants exposed to perinatal asphyxia. 5

Neonatal Hypoxic-Ischaemic Encephalopathy (HIE) is the term used most frequently to designate the clinical and neuropathologic findings thought to occur in full-term infants following intrapartum or neonatal asphyxia. Hypoxia leads to lactate dependent cellular damage, which is the likely cause 
of brain damage. 6 The incidence of perinatal hypoxia is about 1.0 to $1.5 \%$ of live births in most centres and is inversely related to gestational age and birth weight. It occurs in $9 \%$ infants of less than 36 weeks gestation and in $0.5 \%$ infants of more than 36 weeks gestation. ${ }^{7}$

\section{CNS Involvement}

By and large according to presence of primary signs of acute neonatal encephalopathy, the CNS was the most frequently involved (72\%) as documented by Ana Martin et al. ${ }^{7}$ The primary sign of CNS injury following asphyxia included seizures, abnormal respiratory pattern to include apnoea and respiratory arrest, an apparent state of hyperalertness, jitteriness, posturing and movement disorders, impaired suck, swallow, gag and feeding, abnormal oculomotor and pupillary responses, pervasive hypotonia and a bulging of anterior fontanelle. Four neuropathological processes have been associated with perinatal asphyxia; primary subarachnoid

haemorrhage,

Hypoxic-Ischaemic Encephalopathy (HIE), periventricular leukomalacia and intraventricular haemorrhage.

\section{Hypoxic-Ischaemic Encephalopathy}

If the full-term brain has been compromised during delivery, it is likely that the infant will show clinically evident disturbance in neurological behaviour, a state referred to as hypoxic-ischaemic encephalopathy. Infants showing encephalopathic behaviour depending upon the severity and duration of asphyxia event, which includes alteration in alertness, muscle tone and respiration. These clinical features were first graded by Sarnat and Sarnat. ${ }^{8}$

(Modified from Sarnat $\mathrm{H}$; Sarnat $\mathrm{M}$, Neonatal Encephalopathy: Arach Neurol 1976;33 (10)696-705). ${ }^{8}$

\begin{tabular}{|c|c|c|c|}
\hline STAGE & STAGE 1 (Mild) & STAGE 2(Moderate) & STAGE 3(Severe) \\
\hline Level of concioueness & Hyperalert, irritable & Lethargic or obtuned & Stupurous, comstoce \\
\hline $\begin{array}{l}\text { Neuromaccular control } \\
\mathrm{m}\end{array}$ & Uninhibited, overactive & $\begin{array}{l}\text { Diminiched spontaneous } \\
\text { movement }\end{array}$ & $\begin{array}{l}\text { Diminished or sbsent } \\
\text { spontsneous movement }\end{array}$ \\
\hline Muscle tone & Normal & Mild hypotonia & Flascid \\
\hline Posture & Mild distal fiexion & Strong distal flexion & Intermittent decerebration \\
\hline Stretch reflexes & Oversctive & Overactive,disinhibited & Decressed \\
\hline Segmental myocionus & Present or absent & Present & Abesent \\
\hline Complex refiexe: & Normsl & Suppressed & Absent \\
\hline Suck & Weak & Weak or absent & Absent \\
\hline Moro & Strong, low threahold & Weak,incompleate, high & Absent \\
\hline Oculovestibular & Norm: & Overactive & Wesk or abeent \\
\hline Tonic Neck & slight & Strong & Absent \\
\hline Autonomic function & Generalised sympathetic & Genersifeed perasympethetic & Both system decresed \\
\hline Pupil & Mydrissis & Miogis & Mid position/ unequsl \\
\hline Respiration & Sponteneous & Sponteneous; occ apnoes & Periodic; spnoea \\
\hline Heart rate & Tachyeserda & Ersdycardis & Varisble \\
\hline $\begin{array}{l}\text { Bronchisl a: salivary } \\
\text { secretion }\end{array}$ & Sporse & Profuse & varisble \\
\hline Gastrointestins motility & Norms / decresed & increased, diarrhoea & Voriable \\
\hline $\begin{array}{l}\text { Seizures } \\
\mathrm{m}\end{array}$ & None & $\begin{array}{l}\text { Common focal or } \\
\text { multifocs ( } 6-24 \text { hrs age) }\end{array}$ & $\begin{array}{l}\text { Uncommon (exclucing } \\
\text { decerebration) }\end{array}$ \\
\hline $\begin{array}{l}\text { eag findings } \\
v \\
y\end{array}$ & Normal & $\begin{array}{l}\text { Eartygeneralized low } \\
\text { voltage, slowing } \\
\text { Loter-periodic pattern;seizures }\end{array}$ & $\begin{array}{l}\text { Early: periodic pattern } \\
\text { Later :totally } \\
\text { isopotential }\end{array}$ \\
\hline Outcome & About $100 \%$ normal & $80 \%$ normal & About $50 \%$ die \\
\hline
\end{tabular}


Neuropathologic patterns of hypoxic-ischaemic cerebral injury/ patterns predominantly found in term infants

- Selective neuronal necrosis.

- Status marmoratus.

- Parasagittal cerebral injury.

- Focal and multifocal ischaemic brain injury.

Patterns predominantly found in premature infants Periventricular leukomalacia.

\section{MATERIALS AND METHODS}

The present study is a descriptive study, carried out in the NICU of MGM Medical College and LSK Hospital, Kishanganj, Bihar.

\section{Inclusion Criteria}

Neonates admitted in NICU with-

- History of foetal distress as reported by obstetrician.

- State of neurological depression at birth including late cry after 2 - 3 minutes, limpness, apnoea $>1$ minute.

- Need for resuscitative efforts at time of birth.

- Neurological depression afterward during stay in the unit.

\section{Exclusion Criteria}

- Neonates with major systemic malformation

- Those weighing less than 2000 gms at birth.

- Gestational age < 34 weeks from mother's estimation.

A total of 100 neonates were included in the study. All these babies were observed during their stay in NICU and signs and symptoms of various systems involved were noted. Apart from routine investigations like complete blood count, serum electrolytes, renal and liver function tests, these babies were subjected to specialised investigation pertaining to the organ system affected. For example, in neonates with CNS symptoms LP, EEG, USG and CT scan of brain were done. Likewise, those presenting with tachycardia, murmurs, etc. were advised chest X-ray, ECG, Echocardiography etc.

\section{RESULTS}

A total of 100 neonates were included in the study. All these babies were observed during their stay in NICU and signs and symptoms of various systems involved were noted. Apart from routine investigations like complete blood count, serum electrolytes, renal and liver function tests, these babies were subjected to specialised investigation pertaining to the organ system affected. For example, in neonates with CNS symptoms LP, EEG, USG and CT scan of brain were done. Likewise, those presenting with tachycardia, murmurs, etc. were advised chest X-ray, ECG, Echocardiography etc.

\begin{tabular}{|c|c|c|}
\hline Birth Weight & No. of Cases & Percentage \\
\hline $2000-2499$ & 38 & $38 \%$ \\
\hline $2500-2999$ & 46 & $46 \%$ \\
\hline $3000-3499$ & 16 & $16 \%$ \\
\hline Total & 100 & $100 \%$ \\
\hline
\end{tabular}

The mean birth weight was $2.60 \mathrm{kgs}$ with a Std. deviation of $0.32 ; 38 \%$ of asphyxiated babies were low birth weight, i.e. $<2500$ gms. While $62 \%$ were of birth weight $>2500$ gms.

\begin{tabular}{|c|c|c|}
\hline Place of Delivery & No. of Cases & Percentage \\
\hline Inborn & 19 & $19 \%$ \\
\hline Outborn & 81 & $81 \%$ \\
\hline Total & 100 & $100 \%$ \\
\hline \multicolumn{3}{|c|}{$\begin{array}{c}\text { Table 2. Distribution of Cases according to Place of } \\
\text { Delivery }\end{array}$} \\
\hline
\end{tabular}

Only $19 \%$ of the babies in this study were born in the Obs. Dept. of MGM Medical College, i.e. inborn and the rest were outborn.

\begin{tabular}{|c|c|c|}
\hline Mode of Delivery & No. of Cases & Percentage \\
\hline Normal Delivery & 96 & $96 \%$ \\
\hline LSCS & 04 & $04 \%$ \\
\hline Total & $\mathbf{1 0 0}$ & $\mathbf{1 0 0} \%$ \\
\hline \multicolumn{2}{|c|}{ Table 3. Mode of Delivery } \\
\hline
\end{tabular}

In this study, $96 \%$ babies delivered at term by normal vaginal delivery. Only $4 \%$ were born by Lower Segment Caesarean Section (LSCS).

\begin{tabular}{|c|c|c|}
\hline Organ System Affected & No. of Cases & Percentage \\
\hline CNS & 100 & $100 \%$ \\
\hline CVS & 05 & $05 \%$ \\
\hline Respiratory & 15 & $15 \%$ \\
\hline GIT & 05 & $05 \%$ \\
\hline Liver & 03 & $03 \%$ \\
\hline Renal & 02 & $02 \%$ \\
\hline Haematology & 06 & $06 \%$ \\
\hline \multicolumn{2}{|c|}{ Table 4. Distribution of Organ System Involvement } \\
\hline
\end{tabular}

In this all the babies had involvement of CNS. This was followed by respiratory affection in $15 \%$ cases. Involvement of other organ system ranged from $6-2 \%$.

\begin{tabular}{|c|c|c|}
\hline Degree of Encephalopathy & No. of Cases & Percentage \\
\hline HIE I & 21 & $21 \%$ \\
\hline HIE II & 56 & $56 \%$ \\
\hline HIE III & 23 & $23 \%$ \\
\hline Total & $\mathbf{1 0 0}$ & $\mathbf{1 0 0} \%$ \\
\hline \multicolumn{2}{|c|}{$\begin{array}{l}\text { Table 5. Distribution of Cases according to Degree of } \\
\text { Encephalopathy }\end{array}$} \\
\hline
\end{tabular}

In this study, majority (56\%) babies developed grade 2 hypoxic-ischaemic encephalopathy.

\begin{tabular}{|c|c|c|c|c|c|}
\hline & Normal & NDD & Expired & Attrition & Total \\
\hline HIE I & $20(95 \%)$ & 00 & 00 & $01(5 \%)$ & 21 \\
\hline HIE II & $32(57 \%)$ & $08(14 \%)$ & $09(16 \%)$ & $07(12 \%)$ & 56 \\
\hline HIE III & $04(4 \%)$ & $03(13 \%)$ & $19(82 \%)$ & 00 & 23 \\
\hline Total & $\mathbf{5 3}$ & $\mathbf{1 1}$ & $\mathbf{2 8}$ & $\mathbf{0 8}$ & \\
\hline \multicolumn{6}{|c|}{ Table 6. Relation of Grade of Encephalopathy with } \\
Outcome \\
\hline
\end{tabular}

Among the babies in this study, almost all in HIE I and majority of those in HIE II recovered completely. However, the outcome in babies with HIE III was not good with $82 \%$ of them not surviving infancy.

\begin{tabular}{|c|c|c|}
\hline CNS Manifestation & No. of Cases & Percentage \\
\hline HIE & 100 & $100 \%$ \\
\hline Clinical seizures & 74 & $74 \%$ \\
\hline Hydrocephalus & 01 & $01 \%$ \\
\hline Haemorrhage & 01 & $01 \%$ \\
\hline \multicolumn{2}{|c|}{ Table 7. Spectrum of CNS Involvement } \\
\hline
\end{tabular}


Hypoxic-ischaemic encephalopathy was seen in all asphyxiated babies and clinical seizures were observed in $74 \%$ cases.

\begin{tabular}{|c|c|c|}
\hline $\begin{array}{c}\text { Grade } \\
\text { Encephalopathy }\end{array}$ & $\begin{array}{c}\text { Mean Birth } \\
\text { Weight (kg) }\end{array}$ & $\begin{array}{c}\text { Standard } \\
\text { Deviation }\end{array}$ \\
\hline HIE I & 2.66 & 0.38 \\
\hline HIE II & 2.63 & 0.32 \\
\hline HIE III & 2.47 & 0,23 \\
\hline \multicolumn{2}{|c|}{ Table 8. Comparison of Birth Weight in different } \\
Degree of Encephalopathy \\
\hline
\end{tabular}

The difference in the mean birth weight between babies with HIE II and HIE III was found to be significant with pvalue of 0.017 , i.e. $<0.05$. Also, the mean birth weight of all the babies in this study was $2.6 \mathrm{kgs}$ and the difference between this and mean birth wt. of babies with HIE III was found to be significant. A p-value of 0.031 , i.e. $<0.05$.

\section{DISCUSSION}

The present study was carried out in the NICU of Dept. of Paediatrics; MGM Medical College and Hospital, Kishanganj, Bihar. A total of 100 asphyxiated babies satisfying the preformed inclusion criteria who were admitted to NICU during the period from November 2014 - December 2015 were studied.

\section{Sample Size}

In the present study, the sample size was 100 patients with perinatal asphyxia. This is comparable to the sample size of S. Riphagen $^{9}$ et al $(n=130) ; V$ Pierrat ${ }^{10}$ et al $(n=90)$ and $G$ Oswyn ${ }^{11}$ et al $(n=114)$. It is smaller as compared to Prakash $S$ Shah ${ }^{12}$ et al $(n=375)$ and Badwani et al $(n=276)$, but larger than Ong LC ${ }^{13}$ et al $(n=45) ; K_{K^{\prime a r a m}}^{14}(n=63)$ and R Smith ${ }^{15}$ et al $(n=45)$.

\section{Sex Distribution}

In this study, male babies constituted $74 \%$ of study population against $26 \%$ females. This male preponderance may be a marker of still prevailing gender bias in our society. The study conducted by G Oswyn ${ }^{11}$ et al had $59 \%$ males, while V Pierrat 10 et al observed a female preponderance with $53 \%$ females. No association was found between sex of babies and incidence of severity of asphyxia.

\section{Mode of Delivery}

The majority of babies (90\%) in the present study were delivered by the vaginal route and only $4 \%$ cases had been delivered by Caesarean section. A study by G Oswyn ${ }^{11}$ et al included $73 \%$ babies delivered vaginally. And Smith et al ${ }^{15}$ included $62 \%$ babies born by vaginal route. In all those works, majority of asphyxiated babies were delivered vaginally.

\section{Inclusion and Exclusion Criteria}

The inclusion and exclusion criteria in this study were similar to other studies conducted by PS Shah ${ }^{12}$ et al, K Karam ${ }^{14}$ et al, Ong LC ${ }^{13}$ et al, G Oswyn et al and Ellis et al. However, all these works included babies with low $(<5)$ APGAR score at 5 minutes and umbilical acidosis with $\mathrm{pH}$ of $<7.20$.

\section{Birth Weight}

Babies in this study had birth weight ranging between 2100 gms to 3300 gms. Low birth weight babies weighing $<2500$ constituted $38 \%$ of the study population. None of them had macrosomia with birth weight $>4000$ gms. The mean birth weight was $2.60 \mathrm{~kg}$ with standard deviation of 0.32 . The mean weight of babies with HIE III was $2.47 \mathrm{kgs}$, while that of HIE I and HIE II were 2.66 and 2.63 kgs respectively. The difference in mean birth weight between HIE II and HIE III was found to be significant with p-value of 0.017 , i.e. $<0.05$. This observation implies that babies with low birth weight are more prone to develop HIE III. G Oswyn ${ }^{11}$ et al also associated increased risk of birth asphyxia with low birth weight.

\section{CNS Involvement}

In the present study CNS involvement with HIE was seen in all cases of asphyxia, HIE I comprised 21\%; HIE II 56\% and HIE III 23\% cases. Clinical seizures were observed in $74 \%$ cases. Ana Martin ${ }^{7}$ et al in their study found CNS involvement in $72 \%$ cases.

\section{CONCLUSION}

Our study indicates that among asphyxiated babies, of which $81 \%$ delivered outside hospital. Those with birth weight on lower side are more likely to develop HIE III. CNS was affected in all cases. HIE I was diagnosed in $21 \%$ cases, HIE II in $56 \%$ and HIE III in $23 \%$ of study population. To conclude it must be emphasised that a lot more has to be done in order to identify the risk factors, prevention and treatment of birth asphyxia, so that the precious lives and lost intelligence of millions of babies can be saved, and smiles preserved on face of their families.

\section{REFERENCES}

[1] Lawn JE, Cousens S, Zupen J, et al. 4 million neonatal deaths: When? Where? Why? Lancet 2005;365(9462):891-900.

[2] Low JA, Lindsay BG, Derrick EJ. Threshold of metabolic acidosis associated with newborn complications. Am J Obstet Gynecol 1997;177(6):1391-4.

[3] Ambalavanan N, Carlo WA. Hypoxic-Ischaemic Encephalopathy: Nelson textbook of pediatrics. Vol. 1. 19th edn. Philadelphia: WB Saunders 2012: p. 569-73.

[4] Hansen AR, Soul JS. Perinatal asphyxia and hypoxicischaemic encephalopathy. In: Cloharty JP, Eichenwald EC, Hansen AR, et al. eds. Manual of Neonatal Care. $7^{\text {th }}$ edn. Philadelphia: Lippincott Williams \& Wilkins 2011: p. 711-29.

[5] Shankaran S. Laptook AR, Ehrenkranz RA, et al. Whole body hypothermia for neonates with Hypoxicischaemic encephalopathy. $\mathrm{N}$ England J Med 2005;353(15):1574-84.

[6] Myers RE. Experimental models of perinatal brain damage: relevance to human pathology. In: Gluck L, edr. Intrauterine asphyxia and the developing fetal brain. Chicago: Year Book Medical Publishers, Inc., 1977.

[7] Martin-Ancel A, Garcia-Alix A, Gaya F, et al. Multiple organ involvement in perinatal asphyxia. J Pediatr 1995;127(5):786-93. 
[8] Sarnat HB, Sarnat MS. Neonatal encephalopathy following fetal distress: a clinical and electroencephalographic recordings in several asphyxiated term neonates. Arch Dis Child 1976;33(10):696-705.

[9] Shah P, Riphagen S, Beyene J, et al. Multiorgan dysfunction in infants with post-asphyxia hypoxic ischaemic encephalopathy. Arch Dis Child Neonatal Ed 2004;89(2):F152-5.

[10] Pierrat V, Haouari N, Liska A, et al. Prevalence causes and outcome at 2 years age of newborn encephalopathy: population based study. Arch Dis Child Fetal Neonatal Ed 2005;90(3):F257-61.

[11] Oswyn G, Vince JD, Friesen H. Perinatal asphyxia at Port Moresby general hospital: a study of incidence, risk factors and outcome. P N G Med J 2000;43(12):110-20.
[12] Shah PS, Beyene J, To T, et al. Post asphyxia hypoxic ischaemic encephalopathy in neonates: outcome prediction rule within 4 hours of birth. Arch Pediatr Adolesc Med 2006;160(7):729-36.

[13] Ong LC, Kanaheswari Y, Chandran V, et al. The usefulness of early USG, EEG \& clinical parameters in predicting adverse outcomes in term asphyxiated term infants. Singapore Med J 2009;50(7):705-9.

[14] Khaled A, Al-Zohairy YZ, Khaled K. Early Predictors of neurodevelopmental outcome in term infants with postasphyxial hypoxic ischaemic encephalopathy. Int J of Collaborative Research on Internal Medicine \& Public Health 2011;3(11):302-10.

[15] Smith R. Prevalence of neurodevelopmental sequel in infants who suffered moderate to severe neonatal asphyxia. Arch Dis Child Fetal Neonatal Ed 2009;80:F180-98. 